\title{
Children and disability in early childhood education: "special" or inclusive education?
}

\author{
Kerry Purdue
}

I n this article I look at how "special" education thought and practice can act as a barrier to inclusion in early childhood education for children with disabilities and their families. I suggest that changes in thought and practice are necessary if early childhood education is to progress inclusion for all children and families.

Inclusion in education is about identifying and removing the barriers that get in the way of a child's full acceptance, participation, and learning, so that all children receive high-quality, inclusive early educational experiences (Ballard, 1999a; Booth \& Ainscow, 2002). In this article I examine the issue of how early childhood education includes or excludes disabled children. I suggest that one of the most significant barriers that disabled children and their families face in accessing early childhood education involves the belief system of special education.

In relatively recent times early childhood education in Aotearoa New Zealand has determined that it has a commitment to all children. This is evident in Te Whäriki, which promotes inclusiveness and aspirations for all children "to grow up as competent and confident learners and communicators, healthy in mind, body, and spirit, secure in their sense of belonging and in the knowledge that they make a valued contribution to society" (Ministry of Education, 1996b, p. 9), and in government policy, which supports all children's and their families' rights to an early childhood education that is non-discriminatory and inclusive (Minister for Disability Issues, 2001; Ministry of Education, 1996a, 1998; New Zealand Government, 1993, 1998).

The belief system of special education, however, reinforces the idea that disabled children are "special"; they are different, and therefore require different treatment. Special education has been part of education in New Zealand and elsewhere for a considerable period of time and has been provided either as separate treatment within mainstream education or in segregated centres and schools. It is typically accepted as a normal and appropriate approach to issues of disability. I suggest the belief system and the language of special education are barriers to disabled children's inclusion in early childhood education.

\section{Constructing children as special}

In many settings children with disabilities are typically constructed as "special" children, having "special educational needs" and therefore in need of a "special" education. However, literature and research on inclusive education and disability highlights that the language of special needs may act as a powerful barrier to the development of inclusion in education (Barton, 1997; Booth \& Ainscow, 2002; Corbett, 1996). This is because labelling children as having special needs communicates and reinforces particular beliefs about the nature of disability as a function of individual impairment. What is evident is that this language maintains the idea that there are "two kinds of student and two kinds of education, one special and the other typical, ordinary, not 'special"” (Ballard, 1999a, p. 167). Special is a term that constructs the disabled child as different, as "the other", as having significantly different curriculum and teaching needs, and as belonging elsewhere (MacArthur, Dight, \& Purdue, 2000; MacArthur, Purdue, \& Ballard, 2003).

Removing the language of special needs from centres is not an easy task because this vocabulary is firmly embedded in the legislative and policy framework of mainstream early childhood education (Ministry of Education, 1996a, b, c, 1998, 2005; New Zealand Government, 1993, 1998). The language of special needs is part of daily discourse in many early childhood settings and influences a variety of practices. Oliver (1988) states that:

... the definition of special educational need which still dominates today is one that sees it as an individual problem. This individualisation pervades the teaching process, the categorisation and assessment of children, and the practice of professionals ... (p. 16)

However, the likelihood is that a culture of exclusion will remain as long as the terminology of special is part of policies and practices in early childhood education. That is, in retaining the word special we are preserving medical and deficit meanings of disability as well as the exclusionary attitudes and behaviours that emanate from those meanings.

To challenge the exclusion of disabled children from early childhood settings would require identifying exclusionary practice in all its forms, including the language that we use (Corbett \& Slee, 2000). In this regard, creating inclusive cultures would require changing the language that disables and excludes. Hence, forming an alternative language to special needs would be an essential component for the development of inclusion within early childhood settings. Corbett (2001), for example, suggests that, "Inclusion means responding to individual needs, with 
the term 'special' becoming redundant" ( $p$. xiii). In response to this, Booth and Ainscow (2002) suggest that the term special needs be replaced by the term "barriers to learning and participation” (p. 4). Therefore, inclusion would involve the identification and minimising of barriers to learning and participation, and the maximising of resources to support learning and participation (Booth \& Ainscow, 2002). This language more appropriately reflects a social or socialcultural model of disability, where barriers to learning and participation in education are identified as being created through exclusive cultures, policies, and practices. In contrast, a medical and special education model of disability identifies difficulties in education as caused by a child's impairment or deficit (Booth \& Ainscow, 2002). However, changing the language is viewed as only part of a response to exclusion. What is also required is that we strive to confront and remove social and cultural oppression in all its forms if "education for all" is to become a reality for all (Barton, 1997; Corbett \& Slee, 2000).

\section{Exclusion in practice}

At present the field of special education plays a dominant role in constructing disability within mainstream education thought and practice, and acts to maintain certain truths about disability while negating others (Allan, 1999). This was evident in my doctoral thesis research (Purdue, 2004). My research was based on three case studies, each of which involved a critical examination of how early childhood centres responded to children with disabilities. The first case study involved gathering information at seven full-day workshops undertaken at seven locations in the North and South Islands of New Zealand. The early childhood teachers, other professionals, and parents who attended these workshops provided information on centres' policies with regard to children with disabilities and on their own views about issues in this area. The second and third case studies involved participant observation and interviews in a kindergarten and a childcare centre over a 10 -month period. In these settings I was actively involved in the daily programmes of the centres, looking at how they and their communities responded to children with disabilities and their families. In each case study I was interested in understanding how children with disabilities may be included in early childhood settings and how some children with disabilities may experience exclusion from such centres.
Although there were examples of an inclusive approach to disability, a dominant approach was the taken-for-granted special education assumption that disability is a child's problem, an abnormal condition that makes the child damaged, less than human, and therefore not as valued as others. This approach had many and varied consequences for children and their families.

In some centres there was a common belief that children with disabilities were "naturally" the responsibility of special education because they were considered significantly different; they were "not like us" and in need of "expert" help that was beyond the scope of the teacher's role. In these settings some teachers viewed disabled children as abnormal individuals whose needs could not be met within regular early childhood centres. Some children were perceived to be too different, too disabled, and therefore unable to benefit from ordinary early childhood education. As one teacher said:

... if it's a child that [is] just going to

sit there in a bean bag and you're going to have to carry them to change their nappies or feed them, I just don't know...

I just don't know how much a child that's severely disabled would get out of it...”.

(Purdue, 2004, p. 201)

Another consequence of special education was the impact it had on teachers and on the practices of other professionals in these centres. In this research it was evident that the differences between early childhood and special education philosophies and practices acted as a barrier to the full participation and inclusion of children with disabilities. For example, some itinerant professionals adopted an expert approach to support that conflicted with the curriculum, philosophies, and practices of early childhood settings. In the research there are examples of excessive attachment to the child by the support person; special education staff removing the child from activities of the centre and implementing a separate programme; and practices such as one-to-one teaching that prevented peer interactions and failed to recognise the value of natural supports (e.g. peers supporting and assisting learning as they play with and alongside each other) that help rather than hinder the child's inclusion in the centre.

The effects of these kinds of practices were evident: they isolated disabled children from their peers and teachers; excluded children with disabilities from the curriculum and important opportunities to learn and develop; took the responsibility for children with disabilities away from their teachers; and encouraged negative assumptions about disability such as that the needs of children with disabilities are "different" and, as such, they require special intervention, and that teachers do not, therefore, have to take responsibility for these children.

In these kinds of settings, children interacted more with "untrained" aides than they did with their teachers and peers. In this way, disabled children may be seen to have limited access to normal teacher expectations, i.e., quality teaching and the things that teachers see as important for all children when providing education and care and enhancing successful learning; competent role models to learn with and from; and the same goals of early childhood education as other children, including the same opportunities to gain knowledge, understanding, and skills essential for lifelong learning and community participation. Also, teachers who choose not to get involved with disabled children in their centres will not hear these children's voices, will not be able to tune into their interests and preferences, and will not know them well. When teachers fail to engage in reciprocal activities with a child, they will not have the knowledge they need to plan and implement a meaningful and relevant curriculum.

As Thomas and Loxley (2001, p. 26) explain, "The legacy that one hundred years of special education has given to teachers is the idea ... that you need all sorts of special procedures and qualifications to help you to understand them, and all sorts of special techniques before you can make any sort of job of helping them." When such a mindset is in place, teachers' common-sense knowledge of child development, curriculum, and pedagogy, and their experience in teaching young children is doubly mistrusted. Such beliefs work in favour of special education and serve the interests of special education professionals.

The term "special" has become an effective term for managing the challenges of disabled children or any children who are viewed as difficult to teach. In this regard, special education may be seen as a system of social control where those deemed different, demanding, and disruptive can be managed. The discourse of special education forms and justifies the expression of power that is used to control the "imperfect person" (Gergen, 1999, p. 206). The existence of a special 
education system offers teachers an alternative for managing the implied threat of difference. Therefore, teachers may be tempted to reject and exclude children on the basis of lack of resources, teacher training, and other exclusion excuses or "ways out". For example, some centres had statements in their policies that argued against granting children their legal right to access and participate in their local centre on the grounds of the cost of changing the environment. As one teacher said:

If we have to do major alterations to the building and there is another centre just around the corner that has already made those alterations we would suggest to the family to look there ... it comes down to money. If you can accommodate them. (Purdue, 2004, p. 104)

\section{Inclusion as alternative thought and practice}

In a context where special education language and thought is dominant, the idea of inclusion becomes reduced to what Slee (1997) describes as a "technical problem of resource management" (p. 412). It is assumed that "inclusion will be achieved if the requisite resources, material and human, are located alongside the student in the new environment" (p. 412). However, Slee (2000) argues that inclusion "is not an exclusively technical issue to be fixed by a new ensemble of policy, professionals and resources" (p. 1). Thinking of inclusion as a technical problem only, directs attention away from problems in policy, practice, organisation, and ethos; thus inclusion becomes little more than assimilation. Inclusion is not about assimilating disabled children into existing exclusionary structures so that they become "islands in the mainstream" (Biklen, 1985, cited in Corbett $\&$ Slee, 2000, p. 144). Inclusion is described by some writers as an approach to education that addresses "the deep culture of exclusion" that pervades education settings and society, effecting change (Slee, 1997, p. 412).

My research (Purdue, 2004) highlighted that in settings where inclusionary discourses dominated, teachers and management worked together to make the centre a welcoming environment for all children and their families. There was no questioning of their right to be there and teachers were committed to ensuring the centre's policies and practices were inclusive. This meant that when parents of children with disabilities came to enrol their child in such a centre they felt unconditionally accepted. Parents described how their child and family were welcomed as valued members of the centre and how every effort was made to provide them with a sense of belonging. In inclusive early childhood settings teachers took full responsibility for the education and care of children with disabilities, ensuring that they participated fully in all aspects of the curriculum and in the activities of the early childhood centre alongside their peers, facilitating their learning and development. Teachers who supported inclusion were active in identifying and removing barriers to learning and participation for children with disabilities. Modifying the curriculum and environment, adapting teaching approaches, and working collaboratively with others to meet a child's support requirements were ways in which these teachers ensured that a child's learning needs were met. Such teachers also publicly challenged disapproving voices and practices that were seen to be exclusive.

Inclusion is not another name for special needs education, although current language, beliefs, policies, and practices in some environments would suggest otherwise. As Slee (1997) notes, "special education has reinvented itself to stake its claim in this so-called era of inclusion" which has involved "blending dominant disabling discourses into a language of inclusion" ( $p$. 407). As such, teachers and others involved in early childhood settings may believe they are speaking "a language of inclusion", but are really only adopting a revised special education rhetoric which will contribute to the exclusion rather than inclusion of disabled children (Slee, 2000). In this context, while linguistic adjustments may have been made, the essentialist position underpinning the knowledge, practices, and discourses of special education are left unchallenged and unchanged. What tends to exist are different interpretations of inclusion which "misrepresent and thereby underestimate the seriousness of the issues involved and the degree of struggle required for the necessary changes to be realised" (Barton $\&$ Corbett, 1990, cited in Oliver, 1996, p. 85).

\section{Conclusion: inclusion as social justice}

In research advocating for inclusion and social justice for children with disabilities and their families, there is emphasis on children's rights and on the identification and removal of barriers that deny these rights (Ainscow, 1999; Ballard, 1999b; Bray \& Gates, 2000; Fulcher,
1989; Oliver, 1996). This literature suggests that a separate special education system acts as a significant hindrance to children's rights to have an equal place within society (Kenworthy \& Whittaker, 2000). It would therefore seem imperative that alternative ways are found to respond and cater to the needs of children with disabilities, and that protect and promote the rights of all children.

Exclusionary cultures, policies, and practices have been maintained in Aotearoa New Zealand, as in other countries, partly as a result of a dual education system. It can be said that the establishment and existence of a special education system has resulted from the view that there are two types of children: special children whose needs can only be met through specialist expertise and intervention, and other "normal" children. When this kind of thinking and practice exists, it provides a context within which early childhood settings and schools may abdicate their responsibility for teaching all children, because those with disabilities can be catered for elsewhere.

From recent research (Ainscow, 1999; Ballard, 1999b, 2004; MacArthur \& Kelly, 2004) it seems evident that inclusion is dependent on cultures, policies, practices, and organisational structures being underpinned by a social justice and human rights framework, along with appropriate resourcing to support inclusion for all children. Armstrong, Armstrong, and Barton (2000) contend that "the pursuit of an inclusive society involves a very difficult and demanding struggle against those cultural, ideological and material forces which combine to legitimate policies and practices of exclusion" (p. 3). From Slee and Allan's (2001) perspective, inclusion involves challenging and moving beyond a special education approach to disability, difference, and diversity. They point out that, "Inclusive education represents a fundamental paradigm shift ... It is about all students ..." (p. 177) and involves developing educational environments that respond to the needs of all children. In this regard they view inclusive education as "a social movement against educational exclusion ...” p. 177); in particular, a movement opposing the continuance of a special education system that constructs differentness as separate and nonhuman. Early childhood education should instead assert the value of each and every child, who should be welcomed into early childhood centres that are designed in thought and practice for all children. 


\section{Acknowledgements}

Sincere thanks are extended to Jude MacArthur and Keith Ballard for sharing their knowledge, expertise, and experience with me over the years, and for their advice and guidance on this work.

\section{Additional reading}

Booth, T., \& Ainscow, M. (2002). Index for inclusion: Developing learning and participation in schools (2nd ed.). Manchester: Centre for Studies on Inclusive Education.

Booth, T., \& Kingston, D. (2004). Index for inclusion for early years. Manchester: Centre for Studies on Inclusive Education.

From extensive research with parents and teachers, Booth and Ainscow have developed a document that they term the Index for Inclusion. It looks at reform for inclusion as needing to occur in the three areas of cultures, policies, and practices of education settings. The Index for Inclusion for Early Years can help guide dialogue around issues that are central to the inclusion and exclusion of children and families in early childhood settings. For more information go to http://inclusion.uwe.ac.uk/csie/

\section{References}

Ainscow, M. (1999). Understanding the development of inclusive schools. London: Falmer Press.

Allan, J. (1999). Actively seeking inclusion: Pupils with special needs in mainstream schools. London: Falmer Press.

Armstrong, F., Armstrong, D., \& Barton, L. (2000). Introduction: What is this book about? In F. Armstrong, D. Armstrong, \& L. Barton (Eds.), Inclusive education: Policy, contexts and comparative perspectives (pp. 1-13). London: David Fulton Publishers.

Ballard, K. (1999a). Concluding thoughts. In K. Ballard (Ed.), Inclusive education: International voices on disability and justice (pp. 167-179). London: Falmer Press.

Ballard, K. (1999b). International voices: An introduction. In K. Ballard (Ed.), Inclusive education: International voices on disability and justice (pp. 1-9). London: Falmer Press.

Ballard, K. (2004). Children and disability: Special or included? Waikato Journal of Education, 10 315-326.

Barton, L. (1997). Inclusive education: Romantic, subversive or realistic? International Journal of Inclusive Education, 1(3), 231-242.

Booth, T., \& Ainscow, M. (2002). Index for inclusion: Developing learning and participation in schools (2nd ed.). Manchester: Centre for Studies on Inclusive Education.

Bray, A., \& Gates, S. (2000). Children with disabilities: Equal rights or different rights? In A. Smith, M. Gollop, K. Marshall, \& K. Nairn
(Eds.), Advocating for children: International perspectives on children's rights (pp. 32-41). Dunedin: University of Otago Press.

Corbett, J. (1996). Badmouthing: The language of special needs. London: Falmer Press.

Corbett, J. (2001). Supporting inclusive education. A connective pedagogy. London: Routledge Falmer.

Corbett, J., \& Slee, R. (2000). An international conversation on inclusive education. In $\mathrm{F}$. Armstrong, D. Armstrong, \& L. Barton (Eds.), Inclusive education: Policy, contexts and comparative perspectives (pp. 133-146). London: David Fulton Publishers.

Fulcher, G. (1989). Disabling policies? A comparative approach to education policy and disability. London: Falmer Press.

Gergen, K. (1999). An invitation to social construction. London: Sage Publications.

Kenworthy, J., \& Whittaker, J. (2000). Anything to declare? The struggle of inclusive education and children's rights. Disability and Society, 15(2), 219-231.

MacArthur, J., Dight, A., \& Purdue, K. (2000). "Not so special": Values and practices in early childhood education for children with disabilities. Early Education, 24, 17-27.

MacArthur, J., \& Kelly, B. (2004). Inclusion from the perspectives of students with disabilities. set: Research Information for Teachers, 2, 44-48.

MacArthur, J., Purdue, K., \& Ballard, K. (2003). Competent and confident children? Te Whäriki and the inclusion of children with disabilities in early childhood education. In J. Nuttall (Ed.), Weaving Te Whāriki: Aotearoa New Zealand's early childhood curriculum document in theory and practice (pp. 131-160). Wellington: New Zealand Council for Educational Research.

Minister for Disability Issues. (2001). The New Zealand disability strategy: Making a world of difference. Whakanui oranga. Wellington: Ministry of Health.

Ministry of Education. (1996a). Revised statement of desirable objectives and practices (DOPs) for chartered early childhood services in New Zealand. Education Gazette, 139(4), 3349-3550.
Ministry of Education. (1996b). Te Whäriki. He Whāriki mātauranga mō ngā mokopuna o Aotearoa: Early childhood curriculum. Wellington: Learning Media.

Ministry of Education. (1996c, May). Special Education 2000. Wellington: Author.

Ministry of Education. (1998). Quality in action. Te mahi whai hua. Implementing the revised statement of desirable objectives and practices in New Zealand early childhood services. Wellington: Learning Media.

Ministry of Education. (2005). Kei tua o te pae: Assessment for learning. Wellington: Learning Media.

New Zealand Government. (1993). Human Rights Act. Wellington: Author.

New Zealand Government. (1998). Education (Early Childhood Centres) Regulations. Wellington: Author.

Oliver, M. (1988). The social and political context of educational policy: The case of special educational needs. In L. Barton (Ed.), The politics of special educational needs (pp. 13-31). London: Falmer Press.

Oliver, M. (1996). Understanding disability: From theory to practice. London: Macmillan Press.

Purdue, K. (2004). Inclusion and exclusion in early childhood education: Three case studies. Unpublished doctoral thesis, University of Otago, Dunedin.

Slee, R. (1997). Imported or important theory? Sociological interrogations of disablement and special education. British Journal of Sociology of Education, 18(3), 407-419

Slee, R. (2000, July). Talking back to power. The politics of educational exclusion. Keynote speech presented at the International Special Education Congress 2000 conference, University of Manchester, Manchester.

Slee, R., \& Allan, J. (2001). Excluding the included: A reconsideration of inclusive education. International Studies in Sociology of Education, 11(2), 173-191.

Thomas, G., \& Loxley, A. (2001). Deconstructing special education and constructing inclusion. Buckingham: Open University Press. 